\title{
Metode Belajar PQRST Berorientasi Model Pembelajaran Kooperatif Untuk Meningkatkan Hasil Belajar Kognitif Fisika Siswa SMA
}

\author{
Neng Sholihat ${ }^{1}$, Zuhdi Ma'aruf $^{2}$, Zulirfan $^{3}$ \\ ${ }^{1}$ Program Studi Pendidikan IPA Universitas Muhammadiyah Riau \\ ${ }^{2,3}$ Program Studi Pendidikan Fisika Universitas Riau \\ Jl. Tuanku Tambusai, Pekanbaru, 28294 Riau, telp. 0811 ****** \\ e-mail: ${ }^{1}$ nengsholihat.physic@gmail.com
}

\begin{abstract}
Abstrak
Penelitian ini bertujuan untuk mendeskripsikan hasil belajar kognitif siswa dalam pembelajaran fisika melalui penerapan metode belajar PQRST dengan menggunakan model pembelajaran kooperatif di kelas X MAN 1 Pekanbaru. Materi pokok yang dipilih adalah gelombang elektromagnetik. Bentuk penelitian ini adalah pra-eksperimen dengan rancangan the one-shot case study. Subjek penelitian ini adalah siswa kelas X IPA 1 yang berjumlah 27 orang. Instrumen pengumpulan data penelitian ini adalah tes hasil belajar kognitif. Data penelitian dikumpulkan dengan memberikan tes yang dilakukan setelah proses pembelajaran. Data hasil belajar siswa dianalisis melalui analisis deskriptif. Dari hasil analisis data, diperoleh daya serap rata-rata siswa adalah 90,60\% dengan kategori baik, ketuntasan belajar siswa secara klasikal adalah 96,30 \% dengan kategori tuntas, dan ketuntasan materi pelajaran adalah 92,31 \% dengan kategori tuntas. Berdasarkan daya serap rata-rata siswa, maka pembelajaran dinyatakan efektif untuk meningkatkan hasil belajar kognitif siswa.
\end{abstract}

Kata kunci: Metode PQRST, kooperatif, hasil kognitif

\begin{abstract}
This study aims to describe the cognitive learning outcomes of students in learning physics through the application of the PQRST learning method by using cooperative learning models in class X MAN 1 Pekanbaru. The subject matter chosen is electromagnetic waves. The form of this research is pre experimental design of the one shot case study. The subjects of this study were 27 students of class X IPAI. The data collection instrument was a cognitive learning achievement test. The data were collected by using tests after the learning process. Student learning outcomes data were analyzed through descriptive analysis. From the results of data analysis, the average absorption of students is $90.60 \%$ with a good category, students' learning completeness clasically is $96.30 \%$ with a complete category, and completeness of subject matter is $92.31 \%$ with a complete category. Based on the average absorption of students, it can be concluded that the learning is effective to improve students'cognitive learning outcomes.
\end{abstract}

Keywords: PQRST method, cooperative, cognitive outcomes

\section{Pendahuluan}

Pada umumnya, sebagian siswa menganggap bahwa pelajaran fisika itu sangat sulit dan membingungkan, sehingga prestasi belajar siswa masih rendah. Kurangnya prestasi belajar siswa disebabkan karena kurangnya ketertarikan siswa terhadap pelajaran fisika, di samping berbagai faktor yang lain, misalnya dalam penyampaian materi. Penyampaian materi fisika terutama dalam materi pokok yang bersifat teoritis, umumnya guru banyak menggunakan 
metode ceramah. Metode ceramah ini lebih banyak menuntut keaktifan guru daripada siswa itu sendiri, sehingga dalam proses belajar mengajar siswa menjadi pasif.

Kepasifan siswa dalam belajar disebabkan oleh cara belajar siswa yang kurang tepat, terutama pada materi pokok yang bersifat teori. Siswa umumnya banyak malas membaca. Disamping itu, cara membaca siswa khususnya dan masyarakat Indonesia umumnya masih belum tepat. Ini dapat dilihat dari tingkat kecepatan membaca dan menyimpulkan isi bacaan yang masih sangat rendah. Kebanyakan siswa hanya bisa membaca saja tanpa bisa memahami dan mengambil kesimpulan dari setiap bahan bacaannya. Sementara itu, materi pokok yang sifatnya teori banyak menuntut pemahaman yang tinggi dari siswa, artinya siswa bisa menarik kesimpulan dari bahan yang dibacanya. Untuk mencapai itu, siswa harus memiliki strategi dalam membaca.

Berdasarkan wawancara yang penulis lakukan pada guru fisika di MAN 1 Pekanbaru, dikatakan bahwa salah satu materi pokok fisika yang sifatnya teori yang hasilnya belum memuaskan antara lain gelombang elektromagnetik. Ini terlihat dari sebagian siswa (37\%) yang memperoleh nilai di bawah Kriteria Ketuntasan Minimal (KKM) yang ditetapkan oleh sekolah, yaitu 72 untuk pelajaran fisika. Hal ini disebabkan kurang optimalnya keterlibatan siswa dalam proses belajar mengajar serta tingkat pemahaman siswa terhadap materi pelajaran masih rendah.

Dalam kondisi seperti ini, guru dituntut untuk mencari jalan keluarnya agar siswa dapat memahami serta menyimpulkan isi dari bacaan yang dibacanya, salah satunya adalah dengan menerapkan sistem belajar PQRST (Preview, Question, Read, State, Test) yang dikembangkan oleh Thomas F. Staton.[1]

Sistem PQRST adalah suatu sistem yang dibuat untuk menjadikan siswa sebagai seorang pembaca yang efisien dan mudah mengingat suatu bahan bacaan. Sistem PQRST ini dapat dipakai pada pelajaran fisika khususnya materi pokok yang bersifat teori karena pada materi pokok yang bersifat teori dibutuhkan keaktifan siswa yang lebih baik, penguasaan materi serta tingkat pemahaman yang tinggi terhadap suatu bahan bacaan. Dengan menggunakan sistem belajar PQRST, siswa dapat termotivasi untuk lebih aktif dalam membaca sehingga siswa akan memiliki kemampuan sebagai seorang pembaca yang efisien dan akhirnya akan dapat meningkatkan hasil belajar siswa itu sendiri.

\subsection{Model Pembelajaran Kooperatif}

Salah satu model pembelajaran yang menuntut keaktifan siswa adalah pembelajaran kooperatif. Pembelajaran kooperatif adalah pembelajaran dimana siswa dalam berkelompok kecil yang terdiri dari 4-6 siswa belajar dan bekerja secara kolaboratif, dengan struktur kelompok yang heterogen. [2] Ciri-ciri pembelajaran kooperatif adalah sebagai berikut: a.Siswa bekerja dalam kelompok secara kooperatif untuk menuntaskan materi belajarnya.

b.Kelompok dibentuk dari siswa yang memiliki kemampuan tinggi, sedang dan rendah. c.Penghargaan berorientasi pada kelompok. [3]

Penerapan pembelajaran kooperatif terdiri dari enam tahap. Keenam tahap tersebut adalah sebagai berikut, dapat dilihat pada Tabel 1. [3] 
Tabel 1. Tahap Model Pembelajaran Kooperatif

\begin{tabular}{l|l}
\multicolumn{1}{c|}{ Tahap } & \multicolumn{1}{c}{ Kegiatan Guru } \\
\hline $\begin{array}{l}\text { Menyampaikan tujuan pembelajaran dan } \\
\text { memotivasi siswa } \\
\text { Menyajikan informasi }\end{array}$ & $\begin{array}{l}\text { Guru menyampaikan semua tujuan pembelajaran } \\
\text { yang ingin dicapai pada pembelajaran tersebut } \\
\text { Menyajikan informasi kepada siswa dengan jalan } \\
\text { demonstrasi atau lewat bahan bacaan } \\
\text { Menjelaskan kepada siswa bagaimana caranya } \\
\text { Membentuk kelompok belajar dan membantu } \\
\text { kelompok-kelompok belajar }\end{array}$ \\
Membimbing kelompok bekerja dan belajar & $\begin{array}{l}\text { Membimbing kelompok-kelompok belajar pada } \\
\text { saat mereka mengerjakan tugas mereka } \\
\text { Mengevaluasi hasil belajar tentang materi yang } \\
\text { telah dipelajari }\end{array}$ \\
Evaluasi & $\begin{array}{l}\text { Memberikan penghargaan hasil belajar yang } \\
\text { diperoleh individu dan kelompok }\end{array}$ \\
\hline Memberikan penghargaan &
\end{tabular}

\subsection{Metode Belajar PQRST}

Metode adalah cara atau jalan yang harus dilalui untuk mencapai suatu tujuan tertentu. Belajar bertujuan untuk mendapatkan pengetahuan, sikap, kecakapan, dan keterampilan. ${ }^{[4]}$ Membaca adalah suatu proses yang dilakukan serta dipergunakan oleh pembaca untuk memperoleh pesan yang hendak disampaikan oleh penulis melalui media kata-kata atau bahasa tulis. Membaca teliti atau membaca cermat adalah cara dan upaya untuk memperoleh pemahaman sepenuhnya atas suatu bahan bacaan.[5]

Metode belajar PQRST adalah salah satu metode membaca teliti. Menurut Staton, sistem PQRST secara spesifik dirancang untuk membantu siswa memahami dan mengingat isi bacaan yang dibacanya, dimana sistem PQRST tersebut bersifat praktis dan dapat diaplikasikan dalam berbagai pendekatan belajar.[1] Pada metode ini, siswa akan diperintahkan untuk mendekati suatu tugas bacaan dengan menggunakan langkah-langkah berikut ini:
a.Preview (menyelidiki)
b.Question (menanyakan)
c.Read (membaca)
d.State (menyatakan)
e.Test (menguji)

\subsection{Penerapan Metode Belajar PQRST Berorientasi Model Pembelajaran Kooperatif}

Pada metode belajar PQRST, siswa dituntut untuk membaca teliti beberapa literatur untuk memperoleh informasi tentang materi yang akan dipelajari. Penerapan metode belajar PQRST memiliki keunggulan dalam pembelajaran materi yang bersifat teori karena metode ini dirancang untuk membantu siswa memahami dan mengingat isi bacaan yang dibacanya. Pembelajaran kooperatif digunakan untuk mempermudah penerapan metode belajar PQRST, sehingga siswa dapat mendiskusikan materi yang dipelajarinya dengan kelompok kooperatif yang telah ditetapkan oleh guru.

Dengan melihat tahapan dari model pembelajaran kooperatif, maka selanjutnya peneliti mengintegrasikan tahapan metode belajar PQRST menggunakan model pembelajaran kooperatif menjadi beberapa tahap, yaitu :

\section{a. Persiapan}

1)Memilih suatu materi pokok

Materi pokok yang disajikan adalah materi gelombang elektromagnetik.

2)Membuat Rencana Pelaksanaan Pembelajaran (RPP)

Rencana Pelaksanaan Pembelajaran tentang materi yang akan diajarkan.

3)Membuat Lembar Tugas Siswa (LTS) 
Lembar Tugas Siswa dikembangkan berdasarkan langkah metode belajar PQRST.

4)Menentukan skor dasar individu

Skor dasar individu ditentukan berdasarkan skor tes individu pada evaluasi sebelumnya.

5)Membentuk kelompok-kelompok kooperatif

Sebelum memulai pembelajaran, terlebih dahulu dibentuk kelompok-kelompok kooperatif dengan anggota 5-6 orang, yang bersifat heterogen secara akademik.

6)Menentukan jadwal kegiatan pembelajaran

b. Penyajian Kelas

1) Pendahuluan

Pendahuluan menekankan materi yang akan dipelajari siswa dengan metode belajar PQRST dan menginformasikan mengapa hal itu penting dipelajari.

2) Menyampaikan informasi awal

Informasi awal yang disajikan meliputi ruang lingkup materi dan aturan main dalam langkahlangkah metode belajar PQRST.

c.Kegiatan Kelompok

1)Preview (Menyelidiki)

Siswa menyelidiki ruang lingkup materi sehingga diperoleh gambaran yang secukupnya mengenai isi suatu bab yang akan dipelajari.

2)Question (Menanyakan)

Siswa berdiskusi dengan kelompok untuk mengajukan pertanyaan-pertanyaan mengenai materi yang akan dipelajarinya.

3)Read (Membaca)

Siswa melakukan pembacaan secara aktif untuk menentukan jawaban atas pertanyaanpertanyaan yang mereka susun. Kemudian, siswa mendiskusikan jawaban yang benar dari tiap pertanyaan.

4)State (Menyatakan)

Perwakilan kelompok menyatakan hasil kerjanya di hadapan kelas.

5)Test (Menguji)

Guru menguji pemahaman siswa dengan memberikan soal-soal pemantapan untuk didiskusikan di dalam kelompok.

6)Pengumpulan tugas

Guru meminta siswa mengumpulkan hasil kerja mereka untuk dinilai.

d. Evaluasi

Evaluasi dikerjakan secara individu dalam waktu yang telah ditentukan guru. Skor yang diperoleh siswa dalam evaluasi selanjutnya diproses untuk menentukan nilai perkembangan individu yang akan disumbangkan sebagai skor kelompok.

e. Penghargaan Kelompok

Untuk menentukan bentuk penghargaan kelompok, langkah-langkahnya adalah:

1)Menghitung skor individu dan skor kelompok

Skor individu dihitung bertujuan untuk menentukan nilai perkembangan individu akan disumbangkan sebagai skor kelompok. Nilai perkembangan individu dihitung berdasarkan selisih perolehan skor tes terlebih dahulu dengan skor tes terakhir. Dengan cara ini setiap anggota memiliki kesempatan yang sama untuk memberi sumbangan skor maksimal bagi kelompoknya. Kriteria sumbangan skor kelompok terlihat pada Tabel 2.[2]

Tabel 2. Nilai Perkembangan Individu

\begin{tabular}{l|c}
\multicolumn{1}{c|}{ Skor Tes } & Nilai Perkembangan \\
\hline Lebih 10 poin di bawah skor dasar & 5 \\
10 poin sampai 1 poin di bawah skor dasar & 10 \\
Sama dengan skor dasar sampai 10 poin di atasnya & 20 \\
Lebih dari 10 poin di atas skor dasar & 30 \\
\hline Nilai sempurna (tidak berdasarkan skor dasar) & 30
\end{tabular}


2)Memberi penghargaan kelompok

Skor dihitung berdasarkan rata-rata nilai perkembangan yang disumbangkan oleh anggota kelompok. Berdasarkan rata-rata nilai perkembangan yang diperoleh, terdapat tiga tingkat kriteria penghargaan untuk penghargaan kelompok, yaitu :

a)Kelompok dengan rata-rata skor : $0<x \leq 10$ sebagai kelompok baik

b)Kelompok dengan rata-rata skor : $10<x \leq 20$ sebagai kelompok hebat

c)Kelompok dengan rata-rata skor : $20<x \leq 30$ sebagai kelompok super [2]

\subsection{Hasil Belajar Keterampilan Kognitif}

Ranah tujuan pendidikan berdasarkan hasil belajar siswa secara umum dapat diklasifikasikan menjadi tiga, yakni: keterampilan kognitif, keterampilan afektif, dan keterampilan psikomotorik. Tujuan keterampilan kognitif berhubungan dengan ingatan atau pengenalan terhadap pengetahuan dan informasi, serta pengembangan keterampilan intelektual. Taksonomi atau penggolongan tujuan keterampilan kognitif oleh Bloom, mengemukakan adanya 6 (enam) kelas/tingkat yakni:

a.Pengetahuan, merupakan tingkat terendah tujuan keterampilan kognitif berupa pengenalan dan pengingatan kembali terhadap pengetahuan tentang fakta, istilah dan prinsip-prinsip dalam bentuk seperti mempelajari.

b.Pemahaman, merupakan tingkat berikutnya dari tujuan ranah kognitif berupa kemampuan memahami/mengerti tentang isi pelajaran yang dipelajari tanpa perlu menghubungkannya dengan isi pelajaran lainnya.

c.Penggunaan/penerapan, merupakan kemampuan menggunakan generalisasi atau abstraksi lainnya yang sesuai dalam situasi konkret dan situasi baru.

d.Analisis, merupakan kemampuan menjabarkan isi pelajaran ke bagian-bagian yang menjadi unsur pokok.

e.Sintesis, merupakan kemampuan untuk menggabungkan unsur-unsur pokok kedalam struktur yang baru.

f.Evaluasi, merupakan kemampuan menilai isi pelajaran untuk suatu maksud atau tujuan tertentu. [6]

\section{Metode Penelitian}

Penelitian ini dilaksanakan di MAN 1 dengan waktu penelitian selama 2 bulan. Penelitian ini adalah penelitian pra-eksperimen, karena pada penelitian ini hasil belajar kognitif siswa diukur setelah penerapan metode belajar PQRST berorientasi model pembelajaran kooperatif pada materi pokok gelombang elektromagnetik. Subjek penelitian ini adalah siswa kelas X IPA yang berjumlah 27 orang.

Rancangan penelitian yang digunakan dalam penelitian ini adalah rancangan the one-shot case study. Dalam rancangan ini, suatu kelompok dikenakan perlakuan tertentu, setelah itu dilakukan pengukuran terhadap variabel tergantung.[7] Perlakuan dalam hal ini adalah penerapan metode belajar PQRST berorientasi model pembelajaran kooperatif dengan variabel tergantung yang diamati adalah hasil belajar siswa setelah penerapan metode belajar PQRST berorientasi model pembelajaran kooperatif.

Rancangan the one-shot case study tersebut dapat digambarkan sebagai berikut:

\begin{tabular}{|ll|} 
Treatment & Postest \\
\hline $\mathrm{X}$ & $\mathrm{T}$ \\
\hline
\end{tabular}

Dimana: $\quad \mathrm{X}=$ Perlakuan

$\mathrm{T}=$ Hasil belajar $[8]$

\subsection{Instrumen Penelitian}

a.Perangkat Pembelajaran

1)Silabus dan Sistem Penilaian 
2)Rencana Pelaksanaan Pembelajaran (RPP)

3)Lembar Tugas Siswa (LTS)

4)Kuis

b.Instrumen Pengumpulan Data

Instrumen yang digunakan untuk mengumpulkan data adalah tes hasil belajar keterampilan kognitif yang disusun oleh peneliti berdasarkan tujuan pembelajaran. Dalam penelitian ini, tes hasil belajar yang diberikan terdiri dari 13 butir soal yang berbentuk objektif. Tes hasil belajar kognitif ini telah divalidasi dari segi isi (content validity) dan dari segi susunan (construct validity) oleh pembimbing peneliti yang diasumsikan sebagai pakar.

Sebaran butir soal tes hasil belajar pada materi pokok gelombang elektromagnetik dapat dilihat pada Tabel 3.

Tabel 3. Sebaran Butir Soal pada Materi Pokok Gelombang Elektromagnetik

\begin{tabular}{|c|c|c|c|c|c|}
\hline No. & Materi Ajar & No Soal & $\begin{array}{l}\text { Kategori } \\
\text { Soal }\end{array}$ & $\begin{array}{l}\text { Jumlah } \\
\text { Soal }\end{array}$ & Keterangan \\
\hline 1. & Gelombang Elektromagnetik & $\begin{array}{l}1,2,3,4, \\
5\end{array}$ & $\begin{array}{l}\mathrm{C}_{2}, \mathrm{C}_{1}, \mathrm{C}_{3}, \\
\mathrm{C}_{1}, \mathrm{C}_{3}\end{array}$ & 5 & $\mathrm{C}_{1}=$ Pengetahuan \\
\hline 2. & $\begin{array}{ll}\text { Spektrum } & \text { Gelombang } \\
\text { Elektromagnetik } & \end{array}$ & $6,7,8,9$ & $\mathrm{C}_{2}, \mathrm{C}_{3}, \mathrm{C}_{1}, \mathrm{C}_{2}$ & 4 & $\mathrm{C}_{2}=$ Pemahaman \\
\hline 3. & $\begin{array}{l}\text { Gelombang Elektromagnetik } \\
\text { dalam Kehidupan Sehari-hari }\end{array}$ & $\begin{array}{l}10, \quad 11, \\
12,13\end{array}$ & $\mathrm{C}_{1}, \mathrm{C}_{2}, \mathrm{C}_{2}, \mathrm{C}_{2}$ & 4 & $\mathrm{C}_{3}=$ Penerapan \\
\hline \multicolumn{4}{|c|}{ Jumlah Soal } & 13 & \\
\hline
\end{tabular}

\subsection{Teknik Pengumpulan dan Analisis Data}

Data penelitian dikumpulkan dengan memberikan tes hasil belajar setelah penerapan metode belajar PQRST berorientasi model pembelajaran kooperatif.

Data penelitian ini dianalisis menggunakan teknik deskriptif, yaitu persentase, rata-rata (mean), frekuensi, dan grafik batang untuk mendapatkan gambaran tentang hasil belajar siswa meliputi daya serap dan ketuntasan belajar siswa, serta ketuntasan materi pelajaran.[9]

a. Daya Serap dan Efektifitas Pembelajaran

Daya serap siswa didefinisikan sebagai kemampuan penguasaan siswa terhadap materi yang disajikan dalam proses pembelajaran. Daya serap dihitung dari perbandingan antara skor yang diperoleh siswa terhadap skor maksimum yang ditetapkan. Untuk mengetahui daya serap siswa, digunakan ketentuan:

$$
\text { Daya Serap }=\frac{\text { Skor yang diperoleh siswa }}{\text { Skor maksimum }} \times 100 \%
$$

Efektifitas pembelajaran adalah keberhasilan suatu pembelajaran berdasarkan daya serap rata-rata kelas. Setelah kegiatan belajar mengajar dilakukan, maka diketahui efektifitas pembelajaran. Pedoman untuk mengkategorikan daya serap maupun efektifitas pembelajaran ditunjukkan pada Tabel 4.

Tabel 4. Kategori Daya Serap dan Efektifitas Pembelajaran

\begin{tabular}{ccc}
\hline & & Kategori \\
\cline { 2 - 3 } Interval & Daya Serap & $\begin{array}{c}\text { Efektifitas } \\
\text { Pembelajaran }\end{array}$ \\
\cline { 2 - 3 } & Amat Baik & Sangat Efektif \\
$81-100$ & Baik & Efektif \\
$71-80$ & Cukup Baik & Cukup Efektif \\
$61-70$ & Kurang Baik & Kurang Efektif \\
$<61$ & Tidak Baik & Tidak Efektif \\
\hline
\end{tabular}


b. Ketuntasan Belajar

Ketuntasan pembelajaran dapat diartikan sebagai tercapainya tujuan pembelajaran yang dirumuskan oleh guru pada materi pokok tertentu yang ditandai dengan tidak perlunya remedial, baik remedial siswa maupun remedial tujuan pembelajaran.

(1) Ketuntasan Belajar Siswa

Ketuntasan belajar siswa menyatakan relevansi antara metode belajar yang diterapkan dengan karakter siswa. Ketuntasan Belajar Siswa Individual (KBSI) dapat diperoleh dengan menggunakan persamaan 2 .

$$
\text { KBSI }=\frac{\text { Jumlah TP yang dikuasai siswa }}{\text { Jumlah TP keseluruhan }} \times 100 \%
$$

Siswa dinyatakan mencapai ketuntasan belajar jika telah menguasai minimal $75 \%$ materi pelajaran.

Ketuntasan Belajar Siswa Klasikal (KBSK) dapat diperoleh dengan menggunakan persamaaan 3.

$$
\text { KBSK }=\frac{\text { Jumlah siswa yang tuntas }}{\text { Jumlah siswa keseluruhan }} \times 100 \% \text {. }
$$

Dalam penelitian ini, siswa secara klasikal dinyatakan tuntas belajar jika nilai KBSK minimal sebesar $85 \%$.

(2) Ketuntasan Materi Pembelajaran

Materi pelajaran adalah seluruh bahan pelajaran yang disajikan untuk mencapai kompetensi yang ditetapkan dalam tujuan pembelajaran. Untuk menentukan ketuntasan butir tujuan pembelajaran (KTP), persamaan yang digunakan ialah persamaan 4 .

$$
\mathrm{KTP}=\frac{\text { Jumlah Siswa yang menguasai TP }}{\text { Jumlah siswa keseluruhan }} \times 100 \% \text {. }
$$

Adapun suatu butir tujuan pembelajaran dinyatakan tuntas disajikan apabila telah dikuasai minimal oleh $75 \%$ siswa.

Ketuntasan Materi Pelajaran (KMP) dihitung dengan persamaan 5.

$$
\mathrm{KMP}=\frac{\text { Jumlah TP yang tuntas }}{\text { Jumlah TP keseluruhan }} \times 100 \%
$$

Dalam penelitian ini, batas ketuntasan minimal materi pelajaran yang ditetapkan adalah sebesar $85 \%$.

\section{Hasil dan Pembahasan}

Hasil belajar kognitif pada materi pokok gelombang elektromagnetik melalui penerapan metode belajar PQRST berorientasi model pembelajaran kooperatif dianalisis secara deskriptif sehingga diperoleh gambaran hasil belajar siswa yaitu daya serap, ketuntasan belajar siswa, dan ketuntasan materi pelajaran.

\section{a. Daya Serap dan Efektivitas Pembelajaran}

Diperoleh daya serap rata-rata siswa seperti ditunjukkan pada Tabel 5.

Tabel 5. Daya Serap Siswa Pada Materi Pokok Gelombang Elektromagnetik

\begin{tabular}{ccccc}
\hline No. & Daya Serap & Kategori & Jumlah Siswa & Persentase Siswa (\%) \\
\hline 1 & $91-100$ & Amat Baik & 19 & 70,37 \\
2 & $81-90$ & Baik & 3 & 11,11 \\
3 & $71-80$ & Cukup Baik & 4 & 14,82 \\
4 & $61-70$ & Kurang Baik & 1 & 3,70 \\
5 & $<60$ & Tidak Baik & - & - \\
\hline \multicolumn{7}{r}{ Jumlah } & & 27 & 100 \\
\hline
\end{tabular}

Hasil penelitian ini menunjukkan bahwa daya serap siswa pada materi pokok gelombang elektromagnetik adalah baik. Hal ini disebabkan karena materi pelajaran tersebut sesuai melalui penerapan metode belajar PQRST berorientasi model pembelajaran kooperatif, sehingga dapat diserap dengan baik oleh siswa. 
Rata-rata daya serap siswa pada materi pokok gelombang elektromagnetik melalui penerapan metode belajar PQRST berorientasi model pembelajaran kooperatif adalah 90,60\% dengan kategori baik. Hal ini disebabkan karena penerapan metode belajar PQRST menuntut siswa untuk memahami materi dengan baik, bertanggung jawab atas materi yang harus dipelajari sehingga mengakibatkan siswa menjadi lebih aktif dalam proses belajar mengajar dan termotivasi untuk membaca literatur. Pada tiap langkah metode belajar PQRST, siswa lebih aktif mengulang materi yang ia pelajari sehingga materi yang diserapnya akan lebih lama berkesan dalam ingatannya. Dan melalui model pembelajaran kooperatif, siswa dituntut mengungkapkan ide-idenya secara kreatif dan aktif berfikir kritis dalam diskusi kelompok.

\section{b.Ketuntasan Belajar Siswa}

Dari 27 siswa, terdapat 26 siswa yang tuntas dan 1 siswa yang tidak tuntas belajar. Tidak tuntasnya siswa tersebut diperkirakan karena kurang serius dalam pembelajaran. Hal ini juga didukung dengan data hasil observasi keterampilan sosial dan data angket motivasi siswa, bahwa siswa tersebut memiliki rata-rata keterampilan sosial dengan kategori rendah serta ratarata perubahan motivasi dengan kategori sedang.

Pada penelitian ini, secara klasikal persentase ketuntasan belajar siswa pada materi pokok gelombang elektromagnetik melalui penerapan metode belajar PQRST berorientasi model pembelajaran kooperatif adalah 96,30 \% dan dinyatakan tuntas karena memenuhi standar ketuntasan belajar yang telah ditetapkan. Hal ini menyatakan bahwa hampir seluruh siswa telah tuntas belajar.

\section{c.Ketuntasan Materi Pelajaran}

Informasi tentang ketuntasan butir tujuan pembelajaran dan ketuntasan materi pelajaran ditunjukkan pada Tabel 6. Dari 13 tujuan pembelajaran terdapat 12 tujuan pembelajaran yang tuntas dan 1 tujuan pembelajaran yang tidak tuntas. Ketuntasan butir tujuan pembelajaran tertinggi yaitu pada tujuan pembelajaran 9 yaitu menyebutkan karakteristik tiap spektrum gelombang elektromagnetik dan tujuan pembelajaran 12 yaitu menyebutkan 2 dampak negatif penggunaan gelombang elektromagnetik dalam kehidupan sehari-hari. Sedangkan butir tujuan pembelajaran yang tidak tuntas yaitu pada tujuan pembelajaran 5 yaitu menerapkan rumus $s=c x t$ dalam menyelesaikan soal. Tidak tuntasnya tujuan pembelajaran tersebut diperkirakan karena kurangnya pemahaman siswa terhadap soal yang berbentuk penerapan konsep dalam bentuk perhitungan. Hal ini merupakan kelemahan dari metode belajar PQRST yang kurang menekankan pada materi yang berbentuk perhitungan. 
Tabel 6. Ketuntasan Materi Pelajaran

\begin{tabular}{cccc}
\hline No TP & Jumlah Siswa yang Benar & Ketuntasan $(\boldsymbol{\%})$ & Kategori \\
\hline 1 & 25 & 93 & Tuntas \\
2 & 22 & 81 & Tuntas \\
3 & 26 & 96 & Tuntas \\
4 & 24 & 89 & Tuntas \\
5 & 20 & 74 & Tidak Tuntas \\
6 & 26 & 96 & Tuntas \\
7 & 26 & 96 & Tuntas \\
8 & 26 & 96 & Tuntas \\
9 & 27 & 100 & Tuntas \\
10 & 23 & 85 & Tuntas \\
11 & 24 & 89 & Tuntas \\
12 & 27 & 100 & Tuntas \\
13 & 22 & 81 & Tuntas \\
\hline \multicolumn{2}{c}{ Ketuntasan Materi Pelajaran } & $\mathbf{9 2 , 3 1}$ & Tuntas \\
\hline
\end{tabular}

Tujuan pembelajaran pada tes hasil belajar materi pokok gelombang elektromagnetik dapat dikelompokkan berdasarkan ranah kognitif. Informasi tentang distribusi penguasaan siswa pada masing-masing ranah kognitif seperti ditunjukkan pada Tabel 7.

Tabel 7. Penguasaan Siswa pada Ranah Kognitif

\begin{tabular}{ccccc}
\hline \multirow{2}{*}{$\begin{array}{c}\text { Ranah } \\
\text { Hasil Belajar }\end{array}$} & Jumlah TP & \multicolumn{3}{c}{ Banyaknya TP yang Tuntas } \\
\cline { 3 - 5 } & & Jumlah & $\%$ & Kategori \\
\hline $\mathrm{C}_{1}$ (Pengetahuan) & 4 & 4 & 100 & Amat Baik \\
$\mathrm{C}_{2}$ (Pemahaman) & 6 & 6 & 100 & Amat Baik \\
\hline $\mathrm{C}_{3}$ (Penerapan) & 3 & 2 & 66,7 & Kurang Baik \\
\hline
\end{tabular}

$\mathrm{TP}=$ Tujuan Pembelajaran

Dari Tabel 7, dapat dilihat bahwa persentase tujuan pembelajaran yang dikuasai oleh siswa terendah terdapat pada materi pelajaran yang bersifat penerapan, yaitu sebesar $66,7 \%$ dengan kategori kurang baik. Hal ini kemungkinan disebabkan kurangnya pemahaman siswa tentang penerapan materi pelajaran dalam kehidupan sehari-hari, terutama pada materi pelajaran berupa penerapan konsep dalam bentuk perhitungan, seperti soal menghitung jarak yang ditempuh gelombang elektromagnetik pada selang waktu tertentu. Metode belajar PQRST menuntut siswa untuk lebih aktif dalam proses pembelajaran, artinya siswa diharapkan dapat memecahkan masalah melalui membaca literatur. Sedangkan untuk materi yang berbentuk penerapan konsep dalam bentuk perhitungan diperlukan penjelasan yang lebih banyak dari guru. Ini berarti penerapan metode belajar PQRST berorientasi model pembelajaran kooperatif kurang sesuai diterapkan pada materi pelajaran yang bersifat penerapan. Untuk mengatasi hal ini, guru dapat melakukan hal-hal sebagai berikut :

1) Memberikan banyak latihan soal tentang materi yang bersifat penerapan kepada siswa dan memberikan trik - trik pemecahan soal.

2) Membuat suasana belajar menyenangkan sehingga siswa tidak jenuh dalam belajar.

Berdasarkan kriteria ketuntasan yang ditetapkan oleh Depdikbud (1994), secara klasikal ketuntasan materi pembelajaran pada materi pokok gelombang elektromagnetik dengan 
penerapan metode belajar PQRST berorientasi model pembelajaran kooperatif dinyatakan tuntas dengan persentase $92,31 \%$.

\section{Kesimpulan}

Berdasarkan hasil analisis data dalam penelitian ini, dapat disimpulkan bahwa hasil belajar fisika siswa setelah penerapan metode belajar PQRST berorientasi model pembelajaran kooperatif adalah :

1.Rata-rata daya serap siswa adalah $90,60 \%$ dengan kategori baik.

2.Ketuntasan belajar siswa secara klasikal dinyatakan tuntas dengan persentase $96,30 \%$.

3.Materi pelajaran dinyatakan tuntas dengan persentase $92,31 \%$.

Berdasarkan rata-rata daya serap siswa, maka penerapan metode belajar PQRST berorientasi model pembelajaran kooperatif efektif digunakan untuk pembelajaran fisika siswa kelas X IPA 1 MAN 1 Pekanbaru pada materi pokok gelombang elektromagnetik.

Peneliti menyarankan kepada pembaca untuk meneliti tentang penerapan metode belajar PQRST yang dipadukan dengan model discovery learning atau lainnya pada materi pembelajaran teoritis lainnya untuk melihat keefektifan metode belajar PQRST.

\section{Daftar Pustaka}

[1]Gie TL. Cara Belajar Yang Efisien. Yogyakarta: Pusat Kemajuan Studi. 1998.

[2]Slavin R. Cooperative Learning Theory Research and Practice. Bostom: Allyn and Bacon. 1995.

[3]Ibrahim M, dkk. Pembelajaran Kooperatif. Surabaya: UNESA. 2000.

[4]Slameto. Belajar dan Faktor-Faktor Yang Mempengaruhinya. Jakarta: Rineka Cipta. 1995.

[5]Tarigan HG. Membaca Ekspresif. Bandung: Angkasa. 1995.

[6]Dimyati, dkk. Belajar dan Pembelajaran. Jakarta: Rineka Cipta. 2006.

[7]Suryabrata S. Metodologi Penelitian. Jakarta: RajaGrafindo Persada. 2003.

[8]Sugiyono. Metode penelitian pendidikan. Bandung: CV Alfabeta. 2009.

[9]Zulhelmi. Penilaian Hasil Belajar Mata Pelajaran Fisika. Pekanbaru: UR. 2007. 